\title{
Strategy Of Increasing The Competence Of Graduates Of Vocational High School (SMK) Majoring In Business And Management Based Business And Industrialized
}

\author{
Widiyanto \\ Economic on Education, Semarang State University, Indonesa
}

\begin{abstract}
This research aims to (a) identify the current competencies of graduate SMK BM (Vocational High School majority in Business and Management) (b) identify the competencies of manpower (SMK graduates) required DUDI (workplace) (c) recognize the constraints that occur in order to link and match between Vocational School and DUDI (d) to recommend strategies to increase the competence of graduates based DUDI needed.
\end{abstract}

The approach used in this research is qualitative methods with the focus of the research is What competences needed by the DUDI in Semarang in business area at services and retail to meet the Link and Match between Vocational School and Workplace (DUDI).

The results of this research is the first, the competence of SMK graduates needs for workplace are KSAO (Knowledge, Skill, Attitude and Other). Second, the mechanism of DUDI in determining the competence of graduates who are accepted to work in his place based on the the principle of management, therefore, in determining the needs of competence will be based on management strategies. Third, the internal condition of the DUDI likes such as financial, productivity, workload, and efficiency also influences in the process of determining competence needed for DUDI in Semarang. While the external environment that influences include technology development, customer satisfaction and environmental needs, as well as competitors. Fourth, the competence of SMK graduates be provided using PSG (dual education system) to meet the national competence employment standards in Indonesia. Fith factors that influence SMK in shaping the graduate competences is the entire educational components system. Sixth, the constraints in the realization of the competence can be specified as follows: (1) infrastructure and facilities; (2) relationship with DUDI; (3) the curriculum development; and (4) Test Practice competence. Seventh, the involvement of stakeholders in support of link and match need change agent as a bridge between SMK and (DUDI)

Keyword: the competence of Graduates SMK (Vocational School), Competence of DUDI, Link and Match

\section{Introduction}

The purpose of education in SMK included in it majoring in business and management include: (1) prepare learners to be human productive, able to work independently, fill job vacancies exist in the business world and the industrialized world as a middle-level manpower according to competence in the chosen skill programs; (2) prepare learners to be able to choose a career, tenacious and persistent in competed in the work environment, adapt, and develop a professional attitude in the field of expertise that is of interest; (3) to equip learners with competence-competence in accordance with the program of expertise selected. (Depdiknas,2007)

The purpose of education SMK and SMK graduates phenomenon still occurs (mismatch) discrepancies between the SMK and business management with DUDI, 3 things are: first, not all SMK graduates who scored with Adaptive workforce. This outage is due to a garage facility or laboratory work (workshop) a proper and modern, as well as building a strong partnership with the workforce. Second, from the aspect of many faculty teachers SMK who missed in updating skills to suit the times. As a result, many education in SMK implemented in desultory, so its origin only produces graduates without adequate competence; Third, the programs offer SMK is currently effective and efficient. This problem can be seen from the quality graduates who are not able to answer the challenge of the industrialized world (Wibowo,2008).

The graduates of SMK N 2 and SMK N 9 Semarang majority in business and management (SMK$\mathrm{BM}$ ) shown (a) an increased in 3 years period not all graduates could be recruited as a labor, it indicates that there are many manpower from SMK unemployed (more than $40 \%$ ), (b) an increase in the quantity of graduates over the past 3 years does not work according to his field, (c) some of them pursue to College (d) the average number of employed not more than 2 years, the reason the workplace indicates some of graduates not capable doing their job.

Such contradictory phenomena with the Government policy in the field of education that considers that any success on vocational education or SMK thereby increasing the number of compositions of vocational high school (SMK) against high school (SMA) to 70: 30, with the goal to produce a ready-made workforce 
(Kompas Cyber media, 2006). The competence of graduates of the SMK generated is flexible in accordance with the demands of a growing job market (Renstra Monev 2005-2009; 20). Jafar et.all (2008,13-24) currently most graduates SMK has been in accordance with the standards set by the industry which means mostly able to be absorbed in the industry however because many industries which are not liquid or close so many graduates of the CMS is not absorbed.

Many models who have done various parties to address the missing links of match between graduates and SMK and competence required DUDI. Tatang (2006) revealed a model of competence of graduates on increasing readiness and competence of teachers and practice mentor has been done. Judissuseno, (2008) the need for a variety of learning methods have been carried out by teachers in vocational education; Renstra Depdiknas $(2005$ - 2009) reveal the proportion of subjects in practice more than a theory. In reality is still weak planning component of education in SMK, so it can't be absorbed by DUDI. However, the current conditions of capacity and access to graduate SMK on DUDI not depart from its original condition, unable to minimize and eliminate discrepancies of competence conditions SMK graduates and Business Management (SMK BM) with the needs of DUDI.

Factors that affect the link and match are: first, the system in the SMK that enforces a dual system of education is the national education system in which only the cantonal Parliament is the unit of work unit education, where SMK as the executor of a number of rules and systems that are implemented in the national education, therefore the educational management system of national education should refer in this planning objectives, results and the process would be bound by a number of national rules And systems conducted by the industrialized world using the System Management strategies in the development of core competencies. Second, in the development of a model for competencies that lead to links and match must be a nuanced on mutualism symbiosis win - win solution, whereby both parties SMK and the DUDI parties could have benefit and have mutual benefit, it can be argued that the resulting graduates of SMK can meet the expectations of needs competence DUDI, there was one partnership approach developed by Yasin $(2000 ; 227-233)$ where those drawn up in partnership with the learning system based on problems to improve existing skills in prospective employees for DUDI . Therefore, the basis of this partnership is using the plan strategy needs in the business world, partnerships built through three steps that must be traveled to earn a win-win solution. Third, the Model of competence should be done by both sides, it is of course a must qualify, as well as any kind of a model will not have the power to if can not run by interested parties. With regard to the second factor which the advantages of this model will be shared by both sides, for the industry this would be done due to the company's strategic plan and use for the school can also be implemented because it is still in the learning corridor, according to Garavan, \& McGuire. (2001). in a partnership that uses the company's strategic plan will give you the benefit of the experience for students in the real work, this statement is reinforced by Burke (2005) in cooperation between the schools and business world is easy way for the school institution to prepare students students in entering the workforce.

Aim developed and extended SMK is to cover the needs of a market that is more advanced and have a new paradigm, therefore the function of SMK in developing resources must follow what customers wanted. Development of quality human resources should be oriented so that there is a development of the above in terms of technical ability, theoretical, conceptual, which according to opinion Mangkuprawiro (2002: 135) and Martoyo (2000: 62) who says the development of human resources is an attempt to improve the technical, theoretical, conceptual ability, increased capabilities and improved technical skills of moral human beings through education and training.

The purpose of this study is to (a) identify the competencies a graduate SMK BM presently (b) identify the competencies of manpower (SMK graduates BM) as required by DUDI (c) recognize constraints that occur in order to link and match at the school level and the need for DUDI competences (d) to recommend strategies to increase the competence of graduates of SMK BM competence-based DUDI needed

This research using Qualitative Methods, the data source from SMK Negeri at SMK N 2 and SMK N 9 , while for the DUDI thoroughly through the PT Sarana Lindung Upaya, PT Nasmoco, Super Swalayan Sampangan, Indomaret Tambak aji, Gramedia Java Mall, Gramedia Pandanaran and some companies that used students fo Prakerin (Fieldwork). The subject of such research data sources used are informants and documents

Analysis of the data used are (1) reduction of data (data reduction); (2) the exposure data (data display); and (3) the withdrawal and verification conclusion (conclusion drawn/verification). These three activities are exercised during and after data collection

\section{Research Results \\ (a) Identify The Competence Of Graduates of SMK BM Presently}

The DUDI has a partnership with SMK as the proactive activities of SMK, which requires a place for student practice or on the job training for their students. For SMK parties, DUDI is a laboratory where the 
students practice in a real work, who will grab a number of competencies appropriate field. In addition the SMK has interests to place graduates in order to be accepted as a worker in accordance with field expertise dudi

Various views of DUDI about SMK, so far only seen as an institution of secondary education which educates its students to do work, so that their students practice later came to know the work environment. They don't know or don't want to know by the existence of the concept of PSG, where later the students of SMK graduates are expected to be reliable workers. Therefore there are often a little less fun for SMK are looking for a place to practice, there are still many DUDI who refused had appeared as a practice for students of SMK. Or if you want to receive often they put not in accordance with the areas of expertise that should be trained in certain areas primarily for field sales, Office Administration and business tourism services already be said more than $65 \%$ according to the required area of expertise especially for sale can be said to achieve $90 \%$, if not to say $100 \%$.

In the event of recruiting graduate results many DUDI Parties provided an opportunity for SMK graduates, from some of the results of interviewed to DUDI, the recruitment on SMK graduates reach between $20-70 \%$ of the total number of employees. Even reaching $90 \%$ primarily on the operational level, in a DUDI view SMK graduates far better than at the SMA graduates. Even to attract SMK graduates, DUDI often collaborate with SMK to gain labor as in doing Indomart and PT. New Ratna Motor, usually this through academic selection in schools and also results in apprenticeship DUDI. Nevertheless, the parties typically perform various test DUDI was to recruit them as employees, such as psychological test, interview and so, after that the Labor candidate for the program will still get exercise in an apprenticeship at any company.

\section{(b) Identify The Competencies Of Manpower Required DUDI (SMK-BM graduates)}

The mechanism of determining the needs of competency every corporation is very varied type . BUMN generally determine the needs of workers based on the person's retirement plan or the addition of labor. The requirements of competence determined by itemizing the field assignment and analysis of work that will be given to applicant .needs good characteristically replacing the labor pension as well as the addition because the development is based on policy, and this policy is regarded as a strategy by BUMN

BUMN prefer the competence of knowledge as the top priority, followed by skill, attitude and other. Hotel and Travel services company stated attitude as the order of paramount, and followed the competency skill, knowledge and other. Banks and other financial institutions are more worried about further new competencies, skills knowledge, other, and attitude. Self-service supermarket trade/preferred attitude as the order first and followed by the other, skill and knowledge. DUDI automotive type of business, with emphasis on skill and knowledge, other, and attitude. The same determination was carried out by the industry, skill and then seek after knowledge, attitude, and other

\section{(c) Recognizing The Constraints That Occur In Order To Link And Match At The School Level And} The Need For DUDI Competence

The internal factors affecting to DUDI determination of competencies are: Policy/Regulation Center, productivity, efficiency, development plan, business development, strategy, Financials, vision and mission, the workload, and the leadership that technically can be controlled (controllable) while the external factors that affect uncontrollable and competence are: customers, competitors, technology, economic conditions, government regulations.

To external factors can be explained as follows: the customer, is the external environment as the giver of the benefit of the company. The customer is King, this opinion will provide the necessity of granting of maximum services for customers, in new marketing concepts marketing orientation is no longer just a serve but also to create customer (create a customer), according to Potter (2001) this concept requires all out service (service total). Customer satisfaction and service needs require a varied and easily changed, this change must be taken and anticipated by the company. Anticipating failure can be fatal for the company because it would be abandoned by the customer.

Competitors, competitor Strategy will be used as a comparison in testing the effectiveness of the strategy that is executed. Having regard to the advantages and drawbacks of the strategy of the competitors, an enterprise will be able to determine and select the competence needs of workers. An overview can be obtained from the competition capability of the workforce is needed at the moment now and in the future, in other words the competitors will affect to company in determining the DUDI competency needs

Technology, influential large enough on DUDI in shaping the company's performance, with the development of computerized information systems and changing needs of competence, many workers. Its equipment refers to technological change requires high power support worker competence. The use of high technology without the user's ability to be precisely inefficient, therefore in this case needs to be adjusted with the growth of competence technologies applied in the company. 
Economic conditions often change also affects the determination of the competence of workers, it is due to economic conditions will change or modify the corporate strategy, for example on the conditions of a recession, companies are more likely to implement policies of an efficiency rarely forcing the worker to perform work outside of reasonableness, although given extra money

Government regulation is also a consideration for DUDI in determining the needs of competence, lack of regulation on employment where incriminating for DUDI will tend to be avoided in determining the competence of workers. For example the existence of laws pertaining to the protection of labour legislation-the damning for a company making company is not easy to determine the needs of workers

\section{(d) Strategies to Increase The Competence Of Graduates of SMK BM Competence-Based On DUDI Needed}

In the education system then analyzed the presence of four elements or components that exist and must be met within the education system i.e. input, process, output and outcome. Where the input in the form of raw materials in the world of education is a substance that will support the process and ultimately generate appropriate output and outcome expectations

In the dual system education (PSG) implemented by the SMK then element must be already communicated with the user in this case is DUDI. Therefore the concept of link and match since the start of the input up to output and outcome, the two sides have shared responsibility. For it is the essential characteristics in "link and match" competency based DUDI can be divided into four, namely: (a) input; (b) process; (c) outputs; and (d) outcome. Strategy of Improving the SMK graduates competence-based DUDI can be done through the mechanism of DUDI inputs, processes, outputs and outcomes. Input in strategy mechanism of increasing competence are: (a) the determination of the purpose (b) existence of a curriculum-based DUDI (c) endorsement of the quality of students, educators and infrastructure. Processes in the strategy mechanism of increased competence is through a Broad based curriculum and Dual Based program.

To generate output in accordance with the competence DUDI needs. SMK has to give to the student for additional competence test using DUDI competence standard. Outcome in the strategy increased competence will more benefit to both parties i.e SMK and DUDI

\section{Conclusions and Recommendation}

\section{Conclusions}

First, the competence needs of work expected by KSAO (Knowledge, Skill, Attitude and Other). Feedback about the order of importance of DUDI competence expectation above do not always stable but often change. generally the problem attitude became the first order, and further knowledge, skills and abilities, just as additional experience a plus. In the city of Semarang in determining the requirements of competence needs to be very subjective, that is adapted to the conditions of the company such as: financial aspects, turn over, the type of company and its administrators.

Second, the mechanism of DUDI in determining the competence of graduates who are accepted to work in his place, also will not out of its limitations on the principle of management, therefore, in determining the needs of competence will be based on management strategies which include environmental analysis, planning, strategy, the plan needs workers, job analysis and the analysis of the competence of the worker. In development for model competencies needs, implemented through: the identification of competencies, competency models, assessment service, and determination of the source. In Semarang, though not always in recorded in documentation, according to their rules and keep using the rules as mentioned above.

Third, the internal Influences that affect the DUDI process of determining competence in Semarang refer from observation and interviews are: the ability of a financial, productivity, workload, and efficiency. While the external environment that influences includes are: technology development, customer satisfaction and environmental needs, as well as competitors.

Fourth, the competence of graduates of the SMK using PSG system in accordance with the competency to meet the competence of national employment standards, because government regulations of Indonesia for competency in SMK as follows: (1) standard competence of graduates refers to the curriculum of Puskur (The Bureau of National Curriculum); (2) the curriculum of Puskur (The Bureau of National Curriculum)get the verification and validation of stakeholders besides that also refers to SKKNI and the company was by BSNP, (3) involvement of stakeholders on the unit SMK started from the input, process and output to the outcomes. And referring to the case of, it can be said to be the result of standard competencies a graduate according to the needs of the workplace.

Fifth, the factors that influence SMK education organization in shaping the competence of graduates is the entire educational components can be specified as goals, curricula, learning media and evaluation technique. 
All components of the education system may affect the formation of the competencies a graduate, but not all of them are considered influential by the SMK. Factors that are considered highly influential are: curriculum, infrastructure, students, teachers, and place prakerin (workplace practice)

Sixth, the constraints in the realization of the competence to be said on all components of the education system, but which often arise and need to be urgently resolved the solution can break down as follows: (1) and infrastructure; (2) relationship with DUDI; (3) the curriculum development; and (4) Test Practice competence. Therefore during this time the school is always looking for a way out to solve it.

Seventh, the involvement of stakeholders in support of interconnectedness and conformity (links and match) as long as it still impressed not yet maximum therefore needs to be bridged by the agents of change which consists of the results of the partnership between the school and its stakeholders (DUDI), which is expected by the existence of change agents that are capable of accelerating and eliminate constraints link and match. In addition to competency-based DUDI is required, in relation to alignment of competency standards and competence of graduates, graduates are thus necessary for parties to SMK to adopt the way - a way in determining the DUDI $\mathrm{i}$ competency needs . Application of DUDI in determining competence requirement can be done by DUDI, because for this SMK is also often ask to DUDI for competence their need but the DUDI is not yet give maximum response

\section{Recommendation}

First, the importance of identifying competencies for DUDI will make it easier for both parties in aligning perception and adjustment problems of competence of graduates and DUDI expectation. Because of the importance of understanding the competency needs of the SMK Parties and DUDI Parties more enterprising in digging the competence needs of DUDI. How can be attained through, are: (1) the school did the analysis of internal and external environment, particularly on environmental DUDI who would use the graduates; (2) requesting information and confirmation regarding the need for competence DUDI directly on the personnel or HUMAN RESOURCES; (3) take advantage of alumni who are already working in the excavation information needs of competency in the workplace; (4) make a list of competencies needed DUDI and utilize in curriculum development; (5) analyze the gap between DUDI competence needs and competency needs of graduates.

Secondly, the competence needs will be met if DUDI in curriculum development using DUDI models in determining the competence of workers. Therefore in the curriculum need to also include the parameter success for student using DUDI competency standard, and use the mechanism determining the competence of DUDI, using a way of thinking that is by drafting DUDI models competence needs. Activities that can be performed are: (1) learn how to use the mechanism of determination of DUDI standard competence requirements; (2) adopt a mechanism that is often implemented in determining the DUDI need for competence ; (3) where necessary utilize the services of a consultant to undertake the DUDI analysis environment and in drawing up strategies and learning programs; (3) include educators in order to understand the mechanism of determination of competency needs.

Thirdly, in relation between SMK to DUDI often still presence of constraints, it is recommended to utilize services of third parties which was formed as a partnership in the container as an agent of change, for that in shaping the change agent is a good idea to pay attention to: (1) Agent Group-shifter is a partnership that represent the school and DUDI; (2) the need to take advantage of SMK alumni who are already working; (3) that the agent-shifter apart as a bridge connection between the school and DUDI, is also a working group responsible for the keeping in touch and conformity between the school and the DUDI.

Therefore we recommend agent-shifter has a program of work oriented enhancement and relations between the two, and the suitability of such tasks, among others: (1) reviewing the achievement of a standard of competency graduates; (2) explore the competence needs now and anticipate what kind of competence will be needed for the foreseeable future; (3) assist in the development of curricula, the development of the abilities and skills of teachers, as well as information about and development and infrastructure needs of schools.

Fourth, competency-based DUDI is a competence that is expected by DUDI, thus if in the program curriculum development in the SMK should refer to the development of competence exercised by DUDI, i.e. through phasing: identification of competencies, competency models, device standardized assessment, strategy development and resources

\section{References}

[1]. Burke, John (1996); Competency Based Education and Training; UK The Falmer Press, Falmer House

[2]. Diknas (2007);Rencana Strategis Departemen Pendidikan Nasional 2005-2009; Pusat Informasi dan Humas Departemen Pendidikan Nasional ; 2007

[3]. Garavan, T. N., \& McGuire, D. (2001). Competencies and workplace learning: Some reflections on the rhetoric and the reality. Journal of Workplace Learning, 13(4), 144-163. Potter (2001)

[4]. Jafar,Aisyah, Arnidah, Yayu Wahyuni Yuritman, A. Muliati Nur (2008; 23- 35); Optimalisasi Proses Pelaksanaan Uji Kompetensi untuk Meningkatkan Mutu Lulusan Sekolah Menengah Kejuruan; http://www.bpgupg.go.id/ ; Friday, 18 July 2008 08:28 Tim Web 
[5]. Judisseno, Rimsky K (2008); Jadilah Pribadi Yang Kompeten Di Tempat Kerja; PT Gramedia Pustaka Utama Jl. Palmerah Barat 3337 lt 2- 3; Jakarta ; 2008

[6]. Kompas Cyber media, 2006; SMKN 1 Bantul Raih Sertifikat ISO ; Senin, 04 Juni 2007; http://64.203.71.11/kompas-cetak/

[7]. Mangkuprawiro (2002: 135) 'Manajemen Sumber Daya Manusia’ Bandung

[8]. Martoyo (2000: 62) Pengelolaan Karyawan; Gunung Agung, Jakarta

[9]. Porter , Michael E. (1999); What Is Strategy?; HARVARD BUSINESS REVIEW November-December 1996 Copyright @ 1996 by the President and Fellows of Harvard College. All rights reserved.

[10]. Tatang, Permana (2006) ; Pemahaman Konsep Psg Dan Intensitas Bimbingan Terhadap Kemampuan Membimbing Siswa Psg ; INVOTEC, Volume III, No.7, Agustus 2005 :pp 33 - 39 (smk)

[11]. Wibowo, Agus (2008) ; Saatnya Memilih SMK;http://jawabali.com/ada/agus-wibowo/; july 12, 2008; http://suaramuhammadiyah.com)

[12]. Yasin, Mahmoud (2000; 227-233)" System approach to higher learning:the role joint ventures with business" Industrial Management \& Data System 